\title{
Evolving Green Aviation Transport System: A Hoilistic Approah to Sustainable Green Market Development
}

\author{
A. N. Sarkar \\ International Business \& Research, Asia-Pacific Institute of Management, New Delhi, India \\ Email: ansarkar1@gmail.com
}

Received June 24, 2012; revised July 25, 2012; accepted August 10, 2012

\begin{abstract}
Aviation is one of the fastest growing industries as well as transportation modes in the world. Global aviation contributes about $2 \%$ of global greenhouse gas emissions and supports $8 \%$ of the world economic activity in terms of GDP. With the phenomenal growth in air trafficking by the national and international airliners the total carbon space available for flying is getting progressively diminished and the consequential emission levels are also becoming alarming over passage of time. The paper describes the concept of evolution of Green Transport system with focus on manufacturing of green aircraft and sustainable green marketing involving green supply chain. This entails introduction of New and innovative technologies, including aircraft designing, improving operational efficiency, air traffic control \& monitoring etc; combined with emission mitigation efforts towards sustainable growth of the industry, can make enormous improvements in emission control and reduction in a planned and system-based manner. These integrated approaches are proposed to be used to harmonize the systems and processes that can essentially constitute the suggested framework of the Green Aviation Transport system. The paper, inter alia, discusses various conceptual, strategic, technological and economic and environmental dimensions of the Green Aviation transport system with focus on creating new Green Marketing opportunities for the aviation industry in future.
\end{abstract}

Keywords: Green Aviation; Emissions Reduction; Aircraft Designing; Green Marketing; Sustainable Green Aviation Management System

\section{Introduction}

Green Transport is a new concept-an initiative to support sustainable economic development without sacrificing the local and global environment. Green Transport system aims to provide society with a transport system that leaves a smaller physical carbon footprint, uses less energy and produces less $\mathrm{CO}_{2}$ and other harmful pollutants. Careful planning and sympathetic design are key elements in achieving Green Transport in order to make it possible to decrease land use, especially farm land, increase energy efficiency through operational improvements and reduce harmful pollutants by improved energy pricing and socially responsible economic assessment of alternatives [1].

Aviation transports some two billion passengers annually and $40 \%$ of interregional exports of goods by value. Air transport industry generates a total of 29 millions jobs globally. Global aviation contributes at $2 \%$ of global $\mathrm{CO}_{2}$ emissions and supports $8 \%$ of the world economic activity in terms of GDP. The concept of Greening the aviation enterprise in the same breath can be best linked to reduction of emission level in the atmosphere, closest to the point of achieving near carbon neutrality. Of late, there is a growing concern and realization on air safety in one hand environmental health on the other. As a sign of proactive measure, the environmental impact of the growth in vehicle numbers, particularly in the rapidly developing mega cities of different parts of the world, has been reduced by the introduction of stricter emission control norms and standards - and more consistent enforcement of those standards. Changes to vehicle design standards and improvements to emission testing have reduced the impact of the vehicles on the air qualityincluding in the aviation industry.

Global emissions of Green House Gases (GHG's), by and large, affect all conceivable transport systems that are dependant upon fossil-fuel based feedstock-including Aviation Turbine Fuel (ATF). With the phenomenal growth in air trafficking by the national and international airliners the total carbon space available for flying is getting progressively diminished. Though the older fleets of the aircrafts are getting replaced by the new ones with advanced aviation technology and innovative designs, 
this by no means are adequate, as the total number of carriers commissioned in the air-space every year, is growing at a rapid space. This is in response to meteoric rise in global population, economic growth and conesquential fast changing life-style. Given this scenario, what is becoming increasingly critical for the Aviation Industry is to develop State-of-the-Art Technology that minimizes the aviation's emission levels in the atmosphere while air-trafficking.

The paper discusses various conceptual, strategic, technological, environmental and economic dimension of the Green Aviation transport system with focus on creating new Green Marketing opportunities for the aviation industry.

\section{Carbon Emissions from Aviation Industry: Impact on Environment}

Green-House Gas (GHG) emission is a serious universal problem in all transport systems. This problem is increasing manifold with the phenomenal increase in airtrafficking over the years. This section discusses the impact of emissions from the aviation transport operations on environment.

Aviation emissions reflect the level of overall aviation activity. The growth of air travel for the past several decades has been very rapid. Demand for travel services, both passenger travel and freight transportation, is increasing substantially. The majority of aviation emissions occur at higher altitudes, thus generating greenhouse gases and potentially contributing to climate change. Also, under certain conditions, aircraft engine exhaust can produce contrails. Scientists in the US and around the world are researching the potential impact of contrails to see whether they have a significant impact on the greenhouse effect [2]. Global emissions of GHG's rose $61 \%$ from 1970 to 2005 , or roughly $1.4 \%$ per year (Figure 1). $\mathrm{CO}_{2}$ emissions largely dominate and have risen
$86 \%$ (excluding forest fires and post-burn decay) between 1970 and 2005 or $1.8 \%$. Of the estimated $45.4 \mathrm{Gt}$ of GHGs $\left(\mathrm{CO}_{2}\right.$ eq.) emitted globally in 2005, approximately 59\% ( 27 Gt $\mathrm{CO}_{2}$ eq. $)$-resulted from the combustion of fossil fuel. According to estimated global GHG emissions in 2005 were recorded to be less at 42.4 GT $\mathrm{CO}_{2}$ eq. with the following breakdown: $27.1 \mathrm{Gt} \mathrm{CO}_{2}$ (64\%) from energy, $1.3 \mathrm{Gt} \mathrm{CO}_{2}(3 \%)$ from industrial processes, $3.8 \mathrm{Gt} \mathrm{CO}_{2}(9 \%)$ from Land use change and forestry, $6.4 \mathrm{Gt} \mathrm{CO}_{2}$ eq. (15\%) of Methane, $3.3 \mathrm{Gt} \mathrm{CO}_{2}$ eq. ( $8 \%$ ) of Nitrous Oxide and $0.5 \mathrm{Gt} \mathrm{CO}_{2}$ eq. (1\%) of F-gases [2-4].

Transport accounts for a significant share of the global fossil fuel combustion-related $\mathrm{CO}_{2}$ emissions. Total fossil fuel-related $\mathrm{CO}_{2}$ emissions increased from $20.9 \mathrm{Gt}$ in 1990 to $28.8 \mathrm{Gt}$ in 2007 , of which transport accounted for 4.58 (1990) and 6.63 Gt (2007), representing an increase of approximately 45\% [5]. According to the World Energy Outlook 2009 (IEA, 2009), global energy-related $\mathrm{CO}_{2}$ emissions could increase to over $40 \mathrm{Gt}$ by 2030 and transport emissions would make up over 9 Gt of that despite significant mitigation policies built into the reference scenario. In addition to its contribution to climate change, aviation has a number of other impacts, most notably on ambient air quality and subsequently on public health. The major air pollutant from aircraft operations is $\mathrm{NO}_{2}$; and to a considerably minor degree $\mathrm{CO}$, $\mathrm{SO}_{2}$, VOC and PM, while Ozone is formed indirectly by the reaction between $\mathrm{NO}_{2}$ and VOC. Most air quality assessments and emission inventories focus on aircraft emissions released during the landing and takeoff cycle (LTO) of an aircraft below 3000 feet, although 90\% of emissions occur at the cruise cycle [6]. A recent study finds that health impacts from cruise emissions might be five times higher than those at the ground level. Their estimate attributes approximately 8000 premature mortalities to aircraft cruise emissions per year [7].

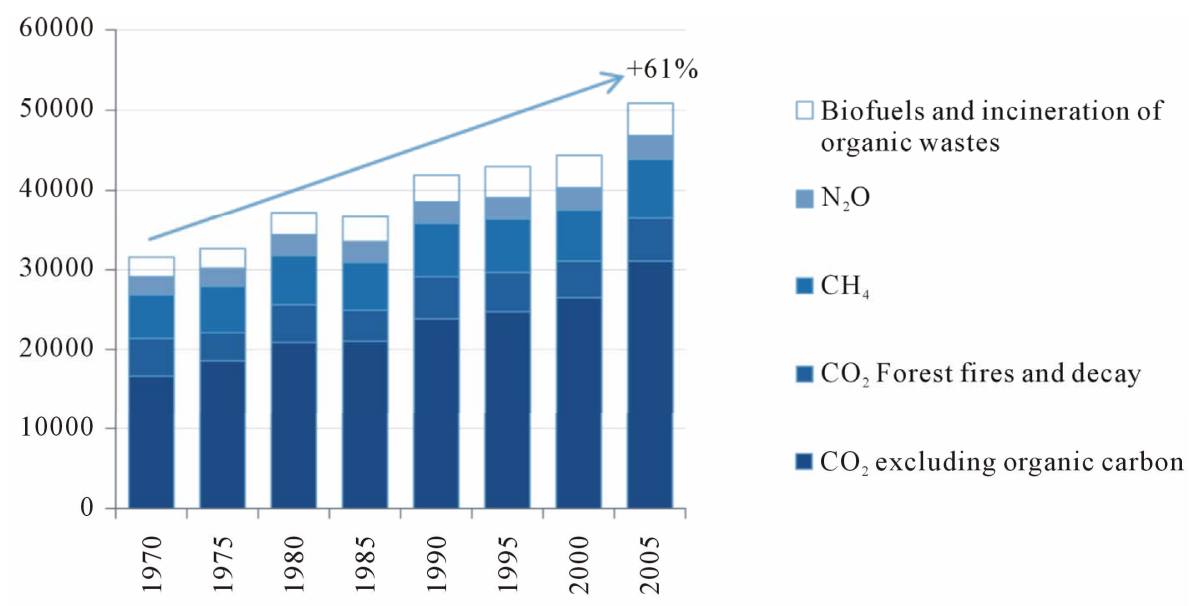

Figure 1. Projected world energy-related $\mathrm{CO}_{2}$ emissions (Mt) [2]. 
According to IPCC, aviation currently accounts for about 2 percent of human-generated global carbon dioxide emissions, the most significant greenhouse gas and about 3 percent of the potential warming effect of global emissions that can affect the earth's climate, including carbon dioxide. IPCC's medium-range estimate forecasts that by 2050 , the global aviation industry, including aircraft emissions, will emit about 3 percent of global carbon dioxide emissions and about 5 percent of the potential warming effect of all global human-generated emissions. Aircraft emits a variety of greenhouse and other gases, including carbon dioxide-the most significant greenhouse gas emitted by aircraft - and nitrogen oxides, as well as other substances such as soot and water vapor that are believed to negatively affect the earth's climate. Emissions from a variety of human-generated sources, including commercial aircraft, trap heat in the atmosphere and contribute to climate change. During flight operations, aircraft emit a number of greenhouse gas and other emissions, including carbon dioxide, nitrogen oxides $\left(\mathrm{NO}_{2}\right)$, soot, and water vapor. Figure 2 shows the primary emissions from commercial aircraft. Carbon dioxide emissions from aircraft are a direct result of fuel (hydrocarbons) burning.

The aviation sector consumes approximately $13 \%$ of the total fossil fuel used in transportation, which corresponds to roughly $2 \%-3 \%$ of the total fossil fuels used worldwide [4]. Given the strong growth trends in air transportation, the aviation sector will increasingly become an important source of Green-House Gases (GHGs) and their impact on local air quality and global climate change is expected to increase in the future. Carbon Dioxide $\left(\mathrm{CO}_{2}\right)$ emission has a strong relation with fuel consumption. There is a strong economic incentive to reduce fuel consumption in aviation. As a result of that, aircraft have become very efficient in their fuel consumption. New and innovative aviation technologies can make enormous improvements in emission control and reduction. Figure 3 shows the relative contributions of industry, transportation, and all other sources to global carbon dioxide emissions and breaks down transportation's share to illustrate the relative contributions of road traffic, aviation, and other transportation sources.

On the basis of available data and assumptions about

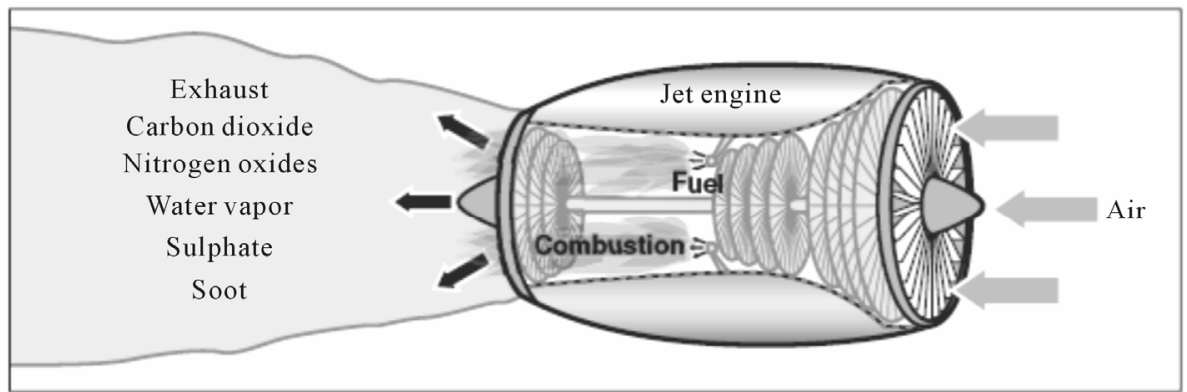

Source: GAO

Figure 2. Selected greenhouse gases and other emissions from aircraft at cruising altitude.

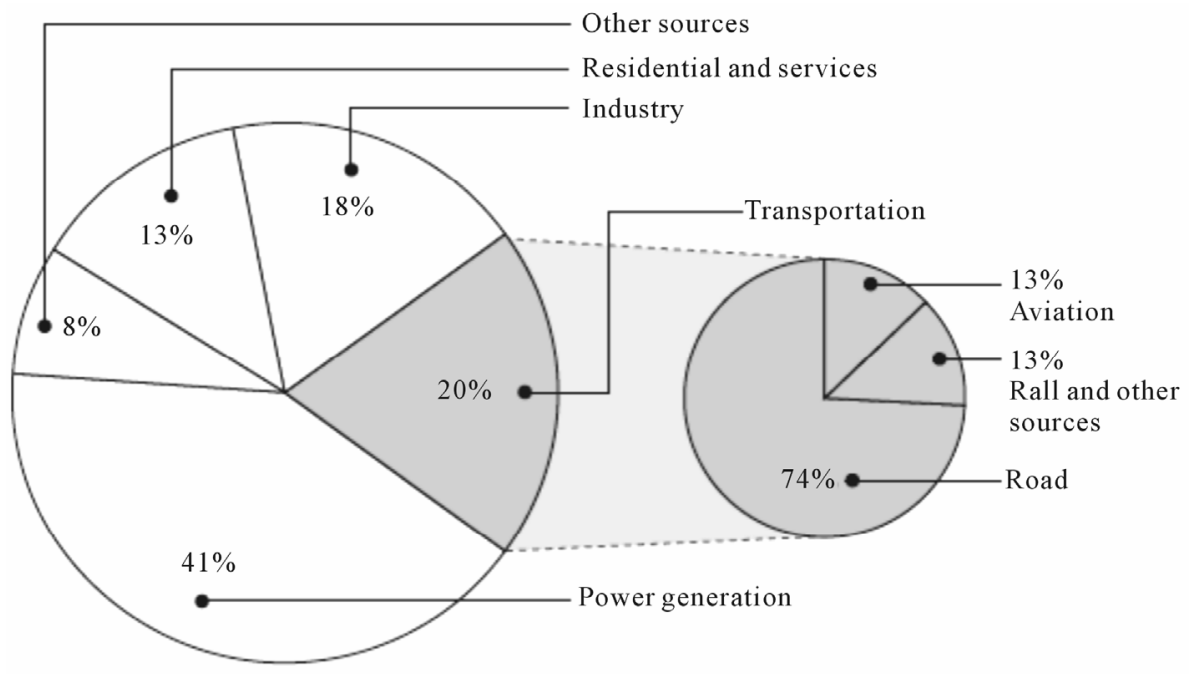

Sources: GAO presentation of International Engrgy Agency and IPCC date.

Figure 3. Global transportation's and global aviation's contributions to carbon dioxide emissions [3]. 
future conditions, IPCC forecasted emissions to 2015 and forecasted three scenarios-low, medium, and high-for growth in global aviation carbon dioxide emissions from 2015 to 2050 [8]. According to EPA, in 2007 commercial aviation represented about 82 percent of all aviation emissions, and about 2.5 percent of US carbon dioxide emissions. In the United States, military aviation represents less than 10 percent of total aviation emissions [9]. While scientific knowledge in this area continues to evolve and remains uncertain the total climate change impact of all aviation emissions is presently estimated to be at least two times greater than the effects of carbon dioxide alone. The estimated additional climate impacts of aviation are not the only reason to take a particular interest in emissions from this sector. A second reason is that emissions from the aviation sector are forecast to grow significantly over time. The Air Transport White Paper (2006) estimated that by 2030, air transport could amount to up to one quarter of the UK's total contribution to global warming.

A study by the Intergovernmental Panel on Climate Change [4], undertaken at the request of ICO, concluded in 1999 that aircraft are estimated to contribute about 3.5 percent of emissions (from human activity) that affect climate change. This is a percentage that is expected to grow because of aviation's rapid rate of growth, and despite improvements in aircraft and engine technology. Policy-making concerning aircraft emissions is being given increasing attention by States following the adoption in 1997 of the Kyoto Protocol to the United Nations Framework Convention on Climate Change (UNFCC), which includes a provision that developed countries, working through the International Civil aviation organization (ICAO) [10], should pursue the limitation or reduction of greenhouse gases from aviation bunker fuels. Accordingly, ICAO has been monitoring advances in technology and has been developing guidance material on operational measures to reduce emissions. ICAO also has been working on policy options to limit or reduce greenhouse gas emissions from civil aviation, including the potential role of market-based options such as emissions-related levies, emissions and voluntary agreements. In 1999, IPCC released its report, Aviation and the Global Atmosphere, conducted at the request of the International Civil Aviation Organization [4] - a United Nations organization that aims to promote the establishment of international civilian aviation standards and recommended practices and procedures. A variety of apex level Federal agencies have played proactive roles in addressing aviation emissions. In 2004, Federal Aviation Administration (FAA) and other organizations including the National Aeronautics and Space Administration (NASA) released a report, Aviation and the Environment: A National Vision Statement, Framework for Goals and Recommended Actions, through the collaborative "PARTNER" programmme stating a general goal to reduce overall levels of emissions from commercial aviation and proposing actions to deal with aviation emissions [11].

According to some forecasts of the two largest manufactures for commercial aircrafts, the air transport system will experience growth rates of $4.9 \%$ [12] to $5.0 \%$ [13] he passenger business and even higher rates in the cargo area (both predict 5.8\%) for the next 20 years. Associated with this increase is an expected demand for up to 29,000 new airplanes in the same timeframe. As a result, the air traffic is projected to double within the next 15 years (Figure 4). The air transport system proved to be resilient to external crises surviving the oil crises of the 1970s, two gulf wars, economic downfalls, the terrorist attacks of 2001 and large area epidemics like SARS in 2002.

Although the whole air transport system accounts today only for approximately $2 \%$ of the global man made carbon dioxide emission [14] the growth rate will not be offset by increased fuel efficiency and thus increasing the share of the $\mathrm{CO}_{2}$ impact with added contributions to global warming. This increased impact is furthermore augmented by the fact that aircraft emissions occur in higher altitudes with more severe implications than ground level emission from other transportation sources. To account for this effect the radiactive forcing index (RFI) is being used by the aviation industry. The IPCC assumes the RFI to be between 2.2 and 3.7 for comercial aviation. The RFI and the projected growth rates explain the major effect of the air transport system on

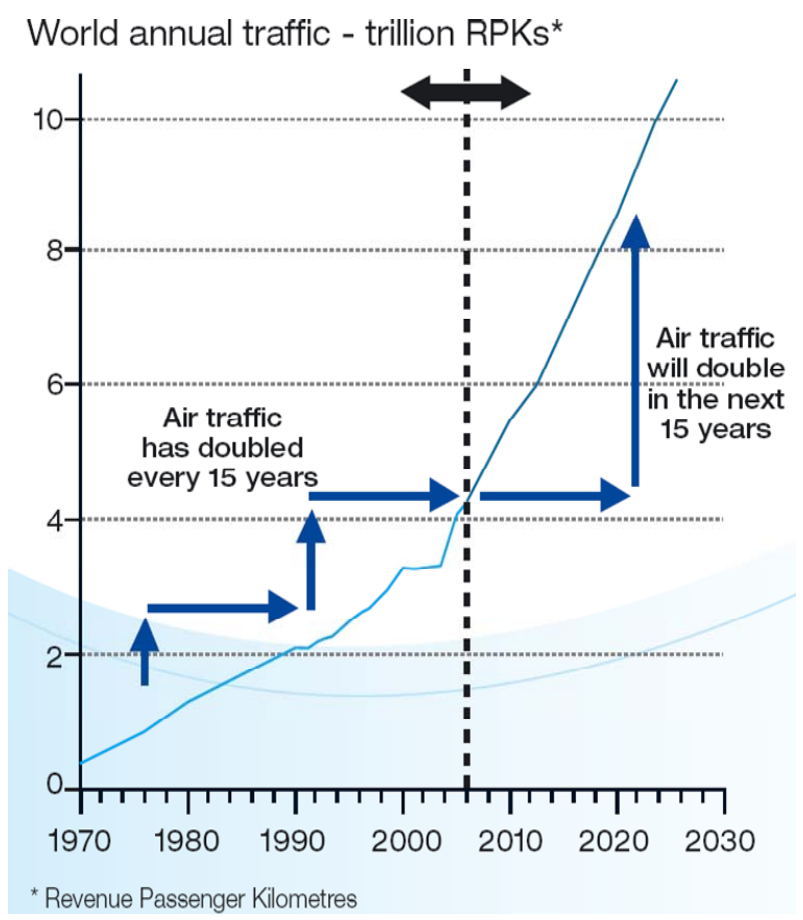

Figure 4. Growth in air traffic between 1970 and 2030 [12]. 
global $\mathrm{CO}_{2}$ emission and therefore the need for improvements in fuel efficiency. This need is furthermore intensified by the high fuel prices directly increasing the airline's operating costs while reducing profitability margins.

Because the majority of aircraft emissions are injected into the upper troposphere and lower stratosphere (typically $9-13 \mathrm{~km}$ in altitude), the resulting impacts are unique. The fraction of these emissions that is relevant to atmospheric processes extends far beyond the radiative effects of $\mathrm{CO}_{2}$. Thus, the impact of burning fossil fuels at altitude is approximately double that due to burning the same fuels at ground level. The enhanced forcing due to aircraft compared with ground-based sources is due to different physical and chemical (e.g., ozone formation/ destruction) effects resulting from altered concentrations of participating chemical species and changed atmospheric conditions. Of the exhaust emitted from the engine core, $7 \%-8 \%$ is composed of $\mathrm{CO}_{2}$ and $\mathrm{H}_{2} \mathrm{O}$, with another $0.5 \%$ composed of $\mathrm{NO}_{2}, \mathrm{HC}, \mathrm{CO}, \mathrm{SO}_{2}$, other trace chemical species, and carbon-based soot particulates. The balance $(91.5 \%-92.5 \%)$ is composed of $\mathrm{O}_{2}$ and $\mathrm{N}_{2}$. Emissions of $\mathrm{CO}_{2}$ and $\mathrm{H}_{2} \mathrm{O}$ are products of hydrocarbon fuel combustion and are thus directly related to the aircraft fuel consumption, which in turn is a function of the weight, aerodynamic design, and engine performance of the aircraft. These emissions are primarily controlled by the engine design, but the total emissions can be reduced through improvements in fuel efficiency and improved aircraft designing.

Internationally binding environmental standards for aircrafts are delineated in Annex 16 to the Convention on International Aviation. Annex 16 consists of Volume I and II, dealing with aircraft noise and aircraft engine emissions, respectively. In order to control local air quality in the vicinity of airports, in 1981 the ICAO adopted International emissions standards for $\mathrm{HC}$ unburned hydrocarbons, $\mathrm{CO}$ (carbon monoxide), $\mathrm{NO}_{2}$ (oxides of nitrogen), and smoke from newly manufactured commercial jet engines. These standards are based on the LTO cycle of an aircraft below $915 \mathrm{~m}$ of altitude. The emission standard for $\mathrm{NO}_{2}$ has been made $50 \%$ more stringent relative to the adoption level in 1981 and will be tightened further by $15 \%$ for newly produced large engines effective on December 31, 2013. A key outcome of the eight meeting of CAEP was the decision to begin working on a $\mathrm{CO}_{2}$ standard that can be adopted by 2013 .

It is critical to distinguish between $\mathrm{CO}_{2}$ and non- $\mathrm{CO}_{2}$ effects of aviation activities on the atmosphere and assess the overall impact of aviation on climate change. For this, the IPCC used the concept of radiative forcing (RF), which is a metric to measure the capacity of a greenhouse gas to alter the energy balance of the atmosphere. Positive RF results lead to a warming of the Earth' sur- face temperature, negative results reflect a cooling effect. In 1992, the RF for global aviation was estimated to be $3.5 \%\left(0.05 \mathrm{~W} \cdot \mathrm{m}^{-2}\right)$ of the total anthropogenic climate impact. This is predicted to increase to $5 \%$ by 2050 .

\section{Improving Operational Efficiency and Aircraft Designs}

Green aviation by implication means improving fuel-use efficiency by improving Operational Efficiency and Aircraft designs; and minimizing all conceivable forms of wastes-including time-lag in between flight scheduling; in take-off as well as landing.

About 98 years ago, the Wright brothers successfully made the first controlled, powered and sustained human flight. This innovative step has continued to stimulate changes in the aviation industry in the face of many challenges, with the main contemporary problem being climate change related. An investigation into what is being done to limit GHG emissions, while keeping flights safe, comfortable and accessible, reveals that technology, operations, and infrastructure support backed by sound management system put on place may all hold the key to reducing mankind's carbon footprint [15]. Aircraft cruise differently, depending on factors such as airframe design, weight, range, weather conditions and the airspace they are flying in. ATM can improve this process. High-tech engines, propeller efficiency, advanced aerodynamics, low-drag airframe and the resulting level of fuel saving have prompted many operators to select turboprops and specially ATR above all others. The proven level of low fuel consumption is a primary concern for airlines eager to lower cash operating cost and wishing to be environment friendly. Less fuel consumption generates less gaseous emissions, matching international recommendations and reducing environmental impact. A successful Green Approach starts already at the Top of Descent. The target is to use all potential energy of the aircraft and convert it to kinetic energy which keeps the aircraft flying during the descent. Descent planning is critical to balance energy versus the needed kinetic energy. Using sophisticated arrival management tools helps to ensure shortest possible and correct track distance. In this case the aim is to allow all aircraft to descend uninterrupted from top of descent without using additional thrust, which burns fuel.

The most important role in an airplane's fuel efficiency is the engines. Jet fuel is one of the highest cost items for an airline, and with the increasingly volatile price of oil, it has become a necessity for the industry to make fuel-efficient engines. The two most-widely used aircraft today - the Boeing 737 and the Airbus A320have shown that newer models of the same aircraft can not only carry more passengers and payload, but do so 
while burning $23 \%$ less fuel. Airbus continues to invest \$265 million annually for research and development for fuel-efficiency. Recent research conducted by the Air Transport Action Group [16] shows that $8 \%$ of all aviation fuel is wasted as a result of route inefficiency. Now, a new form of Air Traffic Management (ATM) is being introduced, with the aim of redesigning routes around the performance of the flight, managing the optimized use of airspace, and allowing computers to plot their own, most efficient, route. Research and experiments conducted by Iberia Spanish Airlines has shown that a reduction of $6 \%-12 \%$ of fuel use can be achieved through this system.

Airports have also joined the effort of the airliners to reduce their adverse environmental impact by developing "green departures" which allow pilots to take-off and climb to their desired altitude in one, smooth ascent For instance, Copenhagen airport has reported a reduction of 32,000 tonnes of $\mathrm{CO}_{2}$ in one year. Another project, focusing on approach and landing operations through a new method called "continuous descent operations" (CDO), where an airplane descends from its optimal altitude in a continuous motion, can lead to fuel savings of up to $40 \%$ during the approach phase. If Europe introduces $\mathrm{CDO}$ more widely, 500,000 tonnes of $\mathrm{CO}_{2}$ could possible be saved (Birmingham's airport has proven that 13,000 tonnes of $\mathrm{CO}_{2}$ were saved in a year using $\mathrm{CDO}$ ). Furthermore, several airports have introduced fixed electrical power units which allow an aircraft to plug in while waiting at the gate instead of burning its engine fuel for power. Zurich Airport has reportedly saved 30,000 tonnes of $\mathrm{CO}_{2}$ per year through installing such units at its 50 gates. London's Heathrow-the world's busiest airport, has also introduced a similar system, which includes pre-conditioned air being delivered to aircraft while at the gate, and has estimated a 100,000 tonnes of $\mathrm{CO}_{2}$ reduction per year.

A key factor that causes an aircraft to burn more fuel and produce greater emissions is an aerodynamic force called drag. Professor Jonathan Morrison and his colleagues from the Department of Chemical Engineering and Chemical Technology are developing a new electroactive plastic for covering aircraft fuselages and wings that can reduce drag by pulsing low-level electrical currents through it. The pulses distort the plastic and therefore the air flowing over the plane, reducing the impact of drag and thereby improving fuel consumption and reducing emissions. Reducing the number of parts and giving the plane a streamlined body makes the plane lighter, creating less drag and improving fuel efficiency. The ultra-high capacity airliner also has three passenger cabins fused together to form one extra wide fuselage, fitting up to 800 passengers. This makes each flight more profitable for airlines, and reduces emissions because fewer flights are made. Fitting more passengers in horizontally, instead of vertically, also means that aircraft are no taller than conventional planes, which means that airports do not need to spend money on restructuring.

Imperial researchers are developing new advanced types of a composite material that can be used by manufacturers to make aircraft structures even stronger and more durable. The material is called a hierarchical composite and it comprises carbon fibres, resin and carbon nano-tubes.

In addition to its environmental benefits, this material can also withstand lightning strikes, a big problem associated with flying, by dissipating the electrical energy from a lightning strike before damage is done to aircraft systems. In 2010, Imperial College, London established the Green Aviation Forum [17] to offer a more integrated response to the complex problems faced in developing a greener air transport system. Technological development affects airlines at both the equipment and the customer service levels. Since 1995, a number of new aircraft types have been certified and introduced into service. These new models incorporate advanced technology and provide for significant improvements in fuel efficiency while reducing noise levels and increasing passenger comfort. Long-range versions of Boeing's 747s, 767s and 777s and Airbus A330's and A340's also permit non-stop ultra-long haul services over extreme and remote terrain.

New air traffic management procedures designed to increase aircraft operational efficiency and reduce emissions may have implications for the management of aircraft noise and noise-sharing across aviation enterprise. These new navigational capabilities often involve introducing changes to existing flight paths which have been designed to minimize noise impacts. Historically, noise abatement procedures have generally been implemented fully recognizing that they will require aircraft to travel greater distances, resulting in the burning of more fuel and increases in emissions. However, some procedures, like continuous descent approaches, have the potential to deliver both fuel burn and noise benefits.

The need for the airline industry to continue to have the capacity to invest in emissions mitigation measures must be central to any approach for developing Green aviation initiatives universally. Key drivers towards achieving carbon-neutral growth to achieve in such mitigation ventures, as well as the associated emission reduction benefits and requiring capital expenditures are summarized as follows [18]:

- Fleet renewal-Airlines will likely need to spend $\$ 1.5$ trillion on new aircraft by 2020 , which will result in a $21 \%$ reduction in $\mathrm{CO}_{2}$ emissions compared to a scenario without fleet renewal. This means 5500 aircraft will be replaced by 2020 , or $27 \%$ of the total fleet.

- Operations-Improved operational practices, includ- 
ing reduced APU (auxiliary power unit) usage, more efficient flight procedures, and weight reduction measures, will achieve 3\% emissions reductions by 2020 . The related costs are estimated at $\$ 1$ billion.

- Infrastructure-Full implementation of more efficient ATM (air traffic management) and airport infrastructure could provide an additional $4 \%$ emissions reduction globally by 2020 , while benefits could be as high as $10 \%$ in some regions. The Single European Sky (SES/SESAR; 70\% cut in route extension), Next Generation ATM in the USA (57\% delay reduction), Pearl River Delta, RVSM (reduced vertical separation minima) over Russia, flex tracks, etc., would require investments of $\$ 58$ billion.

- Engine retrofits \& airframe technology-Modifications to the existing fleet using current technologies (winglets, drag reduction, etc.) could achieve an extra $1 \%$ emissions reduction by 2020 for an estimated investment of $\$ 2$ billion.

- Bio-fuels-Recent tests on bio-fuels have demonstrated that a reduction of $80 \%$ of $\mathrm{CO}_{2}$ emissions, on a full carbon life-cycle basis, can be achieved. Assuming availability of a $6 \%$ mix of 2 nd generation (sustainable) bio-fuels by 2020 , this would reduce aviation $\mathrm{CO}_{2}$ emissions by a further $5 \%$, requiring industry and government investment of $\$ 100$ billion. IATA has set a target to be using $10 \%$ alternative fuels by 2017.

- Offset mechanisms - In order to "close the gap"; 90 million tonnes of $\mathrm{CO}_{2}$ will need to be offset by 2025 to mitigate emissions to 2020 levels and achieve carbon-neutral growth. By 2025, this will cost an additional $\$ 7$ billion per year to achieve.

- Green Take-Offs-Green Departures-There is a large variety of how to perform the environmentally most advantageous takeoff. Today, much consideration is given to noise constraints. Aircraft taking off are in the segment of the flight where they are at their heaviest, meaning that they burn most fuel/time. Aircrafts often climb in a series of steps separated by periods of level flight, neither efficient nor environmentally friendly.

There can be several measures to preserve or improve air quality near airports, which can be summarized to:

- Extensive air quality monitoring;

- Using bio-fuels, natural gas and/or electrical vehicles;

- Reducing aircraft ground operations;

- Reducing delays while taxiing \& idling;

- Performing environmentally advantageous take-offs;

- Imposing emissions-based taxes.

\section{Current Status of Aviation's Emission Mitigation Efforts}

Aviation's emission levels needs to be continuously mo- nitored and controlled through appropriate and systemworthy mitigation and adaptation measures. Green Aviation development is essentially a continuous stream of processes and the milestones can be achieved only by collective efforts from various spheres pf activities such as better aerodynamics in aircraft design and manufacturing; alternative and greener fuel sources such as fuel cells and bio-fuels; efficient engines; route optimization and network development; efficient air traffic management; coercive legislative policies; and positive economic measures.

Efforts are already underway to mitigate GHG emissions in the Aviation sector. For example, airlines regularly retire older aircraft and make adjustments to airframe design through the addition or repositioning of winglets. Future state-of-the-art aircraft, like the Boeing 787 and Airbus A350 (first deliveries of the former are expected in 2010 with the Airbus A350 about three years later), will combine a number of technologies-from lightweight materials to advanced propulsion systemsto achieve even greater fuel efficiency. Nonetheless, in terms of absolute emissions, these gains in efficiency are entirely offset by burgeoning demand. Efforts to improve operational efficiency include the US NextGen initiative, which uses satellites to track aircraft routes and uses the satellite data to shorten travel distances and reduce congestion [19]. A similar initiative known as the Single European Sky ATM Research (SESAR) project is underway in Europe [20].

Some airlines are also testing the possibility of blending jet fuel with alternative fuels. A number of comercial airlines, such as Continental Airlines, have conducted or plan to conduct test flights that make use of bio-fuels. The International Air Transport Association [20] has set a goal for its member airlines to use 10 percent-alternative fuels by 2017. Initial formal technical approval of these new low carbon bio-fuels is expected in 2010. The European Union is on track to integrate the aviation sector into its GHG cap-and-trade system beginning in 2012. The EU regulations cover GHG emissions from all flights either landing at or departing from airports within the European Union [21].

In October 2008, the European Council-as the last of the three European institutions involved in the decisionresolved that air transport would be integrated into the European emissions trading system together with the implicit provision of carbon credit accounting systems. According to this decision, airlines whose flights take off or land in the EU as of 2012 will have to prove that they have allowances covering their respective $\mathrm{CO}_{2}$ emissions. An emission trading is an instrument to limit greenhouse gas emissions that is explicitly mentioned in the Kyoto Protocol and CDM Programmes and Joint Implementation strategies attached to that. The EU launched its 
emissions trading system (EU-ETS) in 2005. It is the first multinational system of its kind [22].

In an effort to tackle aviation's small but fast-growing contribution to climate change, the EU has decided to impose a cap on $\mathrm{CO}_{2}$ emissions for all planes arriving at or departing from EU airports. Airlines would then be allowed to buy and sell "pollution credits" on the EU "carbon market" (Emissions Trading Scheme). International aviation contributes to climate change through different aircraft emissions (carbon dioxide and water vapour emissions, contrails or "aviation smog", indirectly nitrogen oxides). Although the air transport Industry has made improvements to aircraft technology and efficiency, reductions in greenhouse gas emissions (GHG) made thanks to these investments have not been sufficient to compensate for the rapid growth of global air traffic. Since $1990, \mathrm{CO}_{2}$ emissions from aviationwhich are directly related to the amount of fuel consumed-have increased by $87 \%$ and now account for around $3.5 \%$ of total 'human activities' contribution to climate change. The Intergovernmental Panel on Climate Change (IPCC) has estimated that this share will grow to $5 \%$ by 2050 - undermining efforts made by other Industrial sectors to fulfill Europe's Kyoto commitments.

To date, the aviation sector had not been required to do much to address climate change. Indeed, the Kyoto Protocol excludes international aviation and merely requests countries to work towards reducing emissions in this sector through the International Civil Aviation Organization (ICAO). Although the ICAO had initially endorsed the idea of an emissions trading system to meet $\mathrm{CO}_{2}$ emissions reduction objectives, prospects for a comprehensive global agreement appeared distant and, given this situation, the Commission decided to take unilateral action (EurActiv: 01/10/07). Several policy options were examined, including aviation taxes, such as a fuel taxas kerosene is currently exempted from taxation-but this would have required a unanimous decision in the Council of Ministers and was strongly opposed by the aviation industry. In a September 2005 Communication, the Commission finally concluded that bringing aviation into the EU's greenhouse gas emissions trading system (EU-ETS) would be the most cost-effective way of reducing the climate change impact of aviation (EurActiv: $1 / 08 / 05)$.

From 2012 onward, airlines will be issued allowances entitling the emission of a fixed volume of $\mathrm{CO}_{2}$. If an airline produces less $\mathrm{CO}_{2}$, it can sell its allowances in the market to airlines that have higher emission volumes than the permits at their disposal. This enables emissions to be economized where it is possible at the lowest cost - an important advantage over taxes. The integration of air transport into the EU ETS is regulated as follows: Air-lines may buy allowances from companies outside the aviation sector, but their sale is only possible within the sector. As the $\mathrm{CO}_{2}$ mitigation costs in the energy business and industry should on average be lower than in aviation, the sector would probably emerge only as a buyer anyhow. What is more, companies may carry forward the allowances they do not use in a given period to subsequent years. Furthermore, it is possible to buy a certain share of allowances from project-related climate protection mechanisms (Clean Development Mechanism and Joint Implementation) and credit them to one's own reduction target.

The allocation of emission rights is to proceed as follows: The distribution of allowances to the airlines for the 2012 to 2020 period will be based on the ratio between average $\mathrm{CO}_{2}$ emissions of the years 2004 to 2006 and the air transport services performed in 2010. Some $82 \%$ of the allowances will be given to the airlines for free. $15 \%$ will be auctioned within the sector, while $3 \%$ will be reserved for new or strongly growing airlines. As the sector's $\mathrm{CO}_{2}$ emissions have probably risen by roughly 15\% in Europe up to and including 2011, airlines will have to buy the necessary additional allowances in the market; this will boost the actual share to be auctioned to nearly $30 \%$. The basis for the allocation of allowances to the airlines was announced at the end of September 2011, with the total number of allowances to be issued being divided by the total number of tonnekilometres flown. Each airline will thus be allocated permits in accordance with air transport services performed.

\section{Green Aviation Manufacturing}

Green Aviation manufacturing involves transformation of industrial operations in three ways: 1) Using Green energy; 2) developing and selling Green products; and 3) employing Green processes in business operations. A recent global survey by BCG reveals that as many as 92 percent of the companies surveyed are engaged in Green initiatives. Manufacturing companies that adopt Green practices benefit not only through long-term cost savings, but equally importantly, from brand enhancement with customers, better regulatory traction, greater ability to attract talent and higher investor interest. However, these benefits require a long-term commitment and making trade-offs against short term objectives, as the economics of Green manufacturing is still evolving and not well understood as yet. Access to the goals of sustainable development would emphasize the necessity of carefulness in consumption of natural resources. Thus, it is necessary to provide and compile of bases and principles of green business, green productivity and green government in order to economize in limited resources rationally and to retain natural resources for next generations [23]. 
Successful implementation of Green manufacturing requires going beyond small standalone initiatives, and adopting an integrated three-step framework: 1) Planning for Green as a core part of business strategy; 2) executing Green initiatives across the value chain by shifting towards Green energy, Green products and Green processes; and 3) communicating and promoting Green initiatives and their benefits to all stakeholders. The Advisory Council for Aeronautics Research in Europe (ACARE) has set a series of ambitious goals for reducing the environmental impact of aviation. These include reducing carbon dioxide emissions from new aircraft by $50 \%$ per passenger $\mathrm{km}$ (to be achieved from a combination or more efficient aircraft engines, operations and air traffic management measures), reducing nitrous oxide $\left(\mathrm{NO}_{2}\right)$ emissions by $80 \%$ and noise by $50 \%$, all by 2020 (relative to a 2000 base). The ACARE goals are demanding and large scale research and development funding is being made available to support the development of greener aircraft, both domestically and at European level.

Virgin Atlantic, working in conjunction with Boeing and General Electric, has recently announced plans to trial the use of bio-fuel in a commercial aircraft in the near future. In other developments in this area Boeing is working on developing fuel cells to power aircraft airconditioning and electrical systems and is also working on a prototype fuel cell powered light aircraft. However fuel cells are not presently considered a viable option for large scale passenger aircraft [24].

\subsection{Clean-Sky Joint Technology Initiative}

Following the ACARE recommendations, the Clean Sky Joint Technology Initiative was launched in 2007 by the European Commission in cooperation with the industry, research institutes and other partners within the EU. With a budget of 1.6 billion Euros it is one the largest research programs in the EU, lasting from 2007 to 2013. The main goal is to reach the ACARE goal faster in a concentrated effort compared to the usual industry development cycles of 10 years. Clean Sky's main goal is to develop six so called Integrated Technology Demonstrators (ITD) in a multidisciplinary approach for each of those demonstrators. The six ITD covering a broad range of the air transportation systems are Smart Fixed Wing Aircraft, Green Regional Aircraft, Green Rotorcraft, Sustainable and Green Engines, Systems for Green Operations and Eco Design. All of them are linked by a common simulation platform called Technology Evaluator to asses the environmental improvement of the technology developed in the different ITDs using a process based model of the air transport system.

In the fixed wing aircraft project the goal is to reduce aircraft noise by 5 to $10 \mathrm{db}$ and emission from fuel com- bustion by $10 \%$ to $20 \%$ for medium and long-haul aircraft. This is to be achieved by reducing the wing's aerodynamic drag using active and passive flow and load control. The other main area of research will be new aircraft configurations due to new engine concepts. For regional aircraft the main objective is the adaptation of market ready technologies like the use of carbon fibre materials to fit the requirements of regional aircraft. The aircraft engines account for most of the noise and fuel consumption characteristics of airplanes and for the air transportation system. Therefore the development of greener engines is crucial for reaching the ACARE goals and an important part of the Clean Sky initiative. Within the program up to five full sized engines will be produced evaluating new technologies and concepts. Some of those concepts will be explained here. The Systems for Green Operations demonstrator project is part of the holistic approach within the Clean Sky programme. The research covers all flight phases including ground operations with the main objective to reduce noise and emissions. In future, four concepts will be looked at in detail, new aircraft energy concepts, more environmentally friendly trajectories, improved ground operations and as a new operation management approach the Green Mission [25].

\subsection{Carbon-Neutral Growth in Aviation Industry}

Attainment of carbon neutrality with "Zero Carbon" approach is the ultimate goal of the emerging green aviation management system. Such a goal cannot be achieved without proper integration of technological leveraging and evolving sound aviation management and regulatory regime.

The International Air Transport Association [18] announced that the airline industry is committed to achieving carbon-neutral growth by 2020 [26]. The commitment to carbon-neutral growth by 2020 recognizes that technology, operations and infrastructure improvements alone will not be sufficient to stop growth in air transport's carbon footprint. "Positive economic measures are needed to bridge the gap until the full benefits of future technologies - including sustainable bio-fuels - are realized. Carbon-neutral growth $(\mathrm{CNG})$ means that aviation's net $\mathrm{CO}_{2}$ emissions stop growing, even when demand for air transport continues to grow. In other words, net $\mathrm{CO}_{2}$ emissions from aviation would peak from 2020 and would decline after that. CNG will be achieved by investing in measures to cut emissions within the industry or by financing projects to cut an equivalent amount of emissions in other industries. To achieve it, a multi-faceted approach is required with a strong commitment from all aviation stakeholders: Airlines, manufacturers, fuel 
suppliers, airports, and air navigation service providers. The need for the airline industry to continue to have the capacity to invest in emissions mitigation measures must be central to any approach. The IATA's four pillar strategies provide the building blocks to achieve IATA's goals and vision (IATA, 2009). IATA (The International Air Transport Association) represents 230 international member airlines in 125 countries. In an industry that safely flies over 2 billion passengers a year, IATA's members carry $93 \%$ of the world's scheduled international air traffic.

The industry is making great advances in technology such as: Revolutionary new plane designs; new composite lightweight materials; radical new engine advances; and the development of biofuels. Airlines will spend $\$ 1.5$ trillion on new aircraft by 2020 . Some 5500 aircraft will be replaced by 2020 , or $27 \%$ of the total fleet resulting in a $21 \%$ reduction in $\mathrm{CO}_{2}$ emissions compared to business as usual. IATA's Technology Roadmap identifies future technologies that could reduce emissions $20 \%$ to $35 \%$ per aircraft. It provides an overview of aircraft; engine and system technologies that help reduce fuel burn and carbon emissions. It covers steps that are being taken right now such as retrofitting winglets, as well as a range of more innovative technologies, including new engine architecture, composite materials and laminar flow. Modifications to the existing fleet using current technologies (winglets, drag reduction, etc.) could achieve estimated investment of $\$ 2$ billion. But implementing the new technologies identified in the roadmap could provide even bigger savings with fuel burn reductions of $20 \%$ to $35 \%$ per aircraft.

Bio-fuels are an important step in achieving a greener aviation industry as the combustion of fossil fuels increases the amount of $\mathrm{CO}_{2}$ in the atmosphere. Bio-fuels are the only fuel type which plants absorbs $\mathrm{CO}_{2}$ from the atmosphere when they are burnt to derive energy, helping to offset the emissions produced. Bio-fuels differ from fossil fuels in the way that they are not taken out from the earth, but rather, derived from plant matter. At this juncture of time, we are on the path of gradual transformation from fossil fuels to cleaner and greener fuel alternatives. Bio-fuels (such as kerosene manufactured from biomass using the Fischer Tropsch process) and hydrogen produced from renewable sources could also be potentially used in commercial aircraft. The aviation industry has announced plans to trial the use of bio-fuels in aircraft in the near future. There are considerable commercial and technical challenges to be overcome before hydrogen fuelled aircraft could be a reality. Bio-fuelsSustainable bio-fuels for aviation could reduce $\mathrm{CO}_{2}$ emissions $80 \%$, on a full carbon life-cycle basis. IATA's focus is on bio-fuels sourced from second or new generation (e.g. algae, jatropha, camelina) biomass. These fuels can be produced sustainably to minimize impacts on food crops and fresh water usage. Tests in 2008 and 2009 demonstrated that the use of bio-fuel from these sources as "drop-in" fuels is technically sound. No major adaptation of aircraft is required. Bio-fuels can be blended with existing jet fuel in increasing quantities as they become available. Assuming availability of a $6 \%$ mix of 2 nd generation (sustainable) bio-fuels by 2020, this would reduce aviation $\mathrm{CO}_{2}$ emissions by a further $5 \%$, requiring investment of $\$ 100$ billion. IATA has set a target to be using $10 \%$ alternative fuels by 2017 [18]. Aircraft emissions are expected to grow, but technological and operational improvements and Government policies can help control emissions in sky.

For many years, there have been several exploratory studies in academia and industry to build and fly aircraft using sources of energy other than Jet-kerosene or synthetic kerosene (bio-fuels). There have been several success stories in recent years. In March 2008, Boeing successfully conducted a test flight of a manned aircraft powered by PEM hydrogen fuel cells (www.boeing.com). Since fuel cells convert hydrogen directly into electricity and heat without the products of combustions such as $\mathrm{CO}_{2}$, they use a clean or green source of energy. Recently in June 2009 , the prototype of a new solar-powered manned aircraft was unveiled in Switzerland by the company "SOLAR IMPULSE" (www.solarimpulse.com). The airplane is designed to fly both day and night without the need for fuel.

\subsection{Aircraft's Green/Clean Technological Development}

Breakthroughs in many fields have provided evolutionary improvements in performance. Although the aircraft configuration, as of now looks similar, reductions in cost by nearly a factor of 3 since the 707 have been achieved through improvements in aerodynamics, structures and materials, control systems, and propulsion technology. The currently largest available aircraft, the Airbus A380, can host 550 passengers in a three-class configuration and up to almost 800 passengers if all seats would be short-pitch economy class. A preliminary design study for such an ultra high capacity aircraft shows advantages in terms of costs and fuel consumption (and thus $\mathrm{CO}_{2}$ emission) of roughly 10 percent per flown seat per kilometer. Disadvantages are also found, ranging from psychological resistance by both potential passengers and crew to fly with so many people together in one plane, to dimensional restrictions as this aircraft would not fit the currently-used $80 \times 80$ meter box that forms the largest sized aircraft that an airport can handle. An artistic impression of what such a large aircraft looks like can be seen in Figure 5.

Looking at past experiences, the development of a 


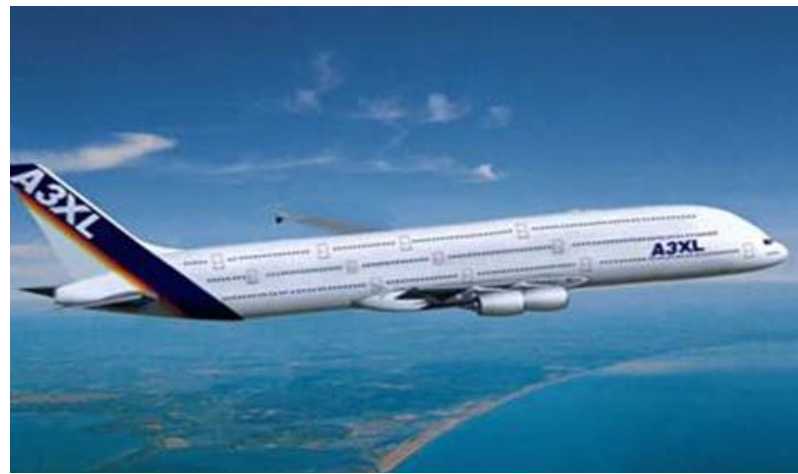

Figure 5. A sketch of a possible ultra high capacity aircraft for 1001 passengers. Source: H. J. K. Lemmen, modification of an Airbus website picture.

prototype of a new aircraft technology and certifying it for use in aviation takes approximately 10 years. That figure is the minimum amount of time, because it holds true for developments such as the A380, which, although it is much larger and contains many innovations and challenges, basically is a newer version of a conventional aircraft. The aircraft design paradigm of a cigar-like fuselage with halfway two wings and a tail section at the end is as old as the early 1950s. Newer design paradigms, like the described Blended Wing Body will take longer than 10 years to develop.

Clearly, technology can reduce the emissions of $\mathrm{CO}_{2}$ from aviation when measured in $\mathrm{kg} \mathrm{CO}_{2}$ per seat flown per kilometer. However, only the total amount of $\mathrm{CO}_{2}$ emitted is important for the issue of climate change, and, full benefits from technologies appear in the very long run. When aviation demand has increased by approximately 250 to 900 percent in these far points in time (2050), a 15 - 25 per cent or even 50 percent reduction in $\mathrm{CO}_{2}$ emissions due to new technology is (by far) not enough to reduce the total $\mathrm{CO}_{2}$ emission of aviation. Improvement in performance is achieved by moving from a component-based design to a fully integrated design by including wing, tail, belly fairing, pylon, engine, high lift devices etc. into the solution. A $20 \%$ improvement in fuel efficiency is projected by 2015 and a $40 \%$ to $50 \%$ improvement by 2050 relative to the aircraft currently produced. Figure 6 shows that fuel efficiency is projected to improve to 3 litres per pax/100km by 2025 [10].

However, a study by the International Council for Clean Transportation [27] shows that while average aircraft efficiency has improved annually by $1.5 \%$ between 1960 and 2008, this improvement has not occurred continuously over time. In fact, efficiency in terms of seat$\mathrm{km}$ and ton-km only increased significantly. In the past two New Commercial Jet Aircraft decades efficiency improvements have been much lower than the often cited $1.5 \%$ per annum.

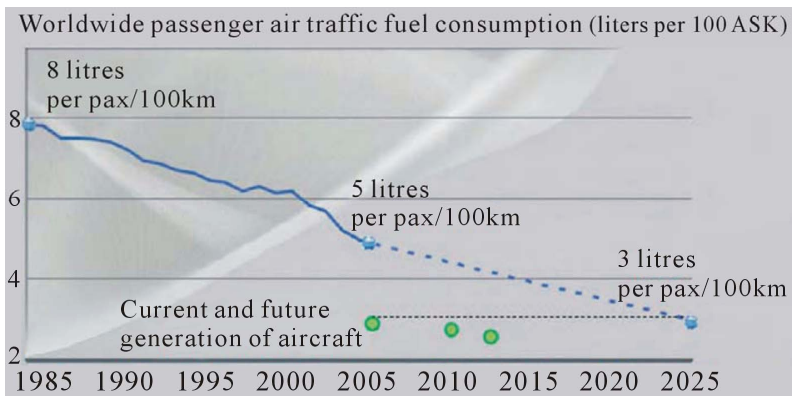

Figure 6. Air traffic fuel efficiency and today's aircraft [27].

There are three key drivers in emissions reductions [28] as shown in Figure 7: 1) Innovative engine technologies and aircraft designs; 2) the improvement in ATM and operations; and 3) the alternative fuels e.g. bio-fuels. The three-prong approach can achieve the goals enunciated by ACARE and NASA by 2020 and beyond.

\section{6. “Green Aviation” Market Analysis}

Green aviation market is vastly expanding with the increasing consciousness towards embracing eco-friendly and noise-free life-styles. To implement this, there is a clear need for tightening regulations on the aviation industry to curb its emissions to drive green aviation technology market in general and the aviation bio-fuels and fuel cells market in particular.

Green Aviation is about efficiency gains as well as reducing the absolute emissions by aircraft. Hence part of the solution to the problem is to find alternative fuels which would not need any modification to existing aircraft designs or fueling infrastructure in the short run, emit less carbon than traditional crude oil based kerosene and yet prove to be more economical than fossil fuels. The global aviation market is striving hard to overcome the challenges of rising operational costs, low revenue growth and the need to meet targets to mitigate greenhouse gas emissions from aviation. All these challenges can only be overcome with a planned strategy which will also lead to the healthy development of air transportation. The green aviation market was estimated to be worth $\$ X X m$ in 2005. The green aviation market rose to $\$ X X m$ in 2008, with a Compound Annual Growth Rate (CAGR) of $\mathrm{XX} \%$. GBI Research foresees the global green aviation market to be worth $\$ X X$ billion in size, with a CAGR of XX\% for the forecast period 2010-2020. GBI Research believes that in the years ahead, the aviation industry will turn to green technologies in order to develop business-led solution to address climate change. GBI Research anticipates the green aviation market will reach $\$ X X$ billion in 2020 from $\$ X X m$ in 2009 [29].

The global aviation industry is increasingly showing sensitivity toward environmental concerns and is choosing to invest in green technology products. However, the 


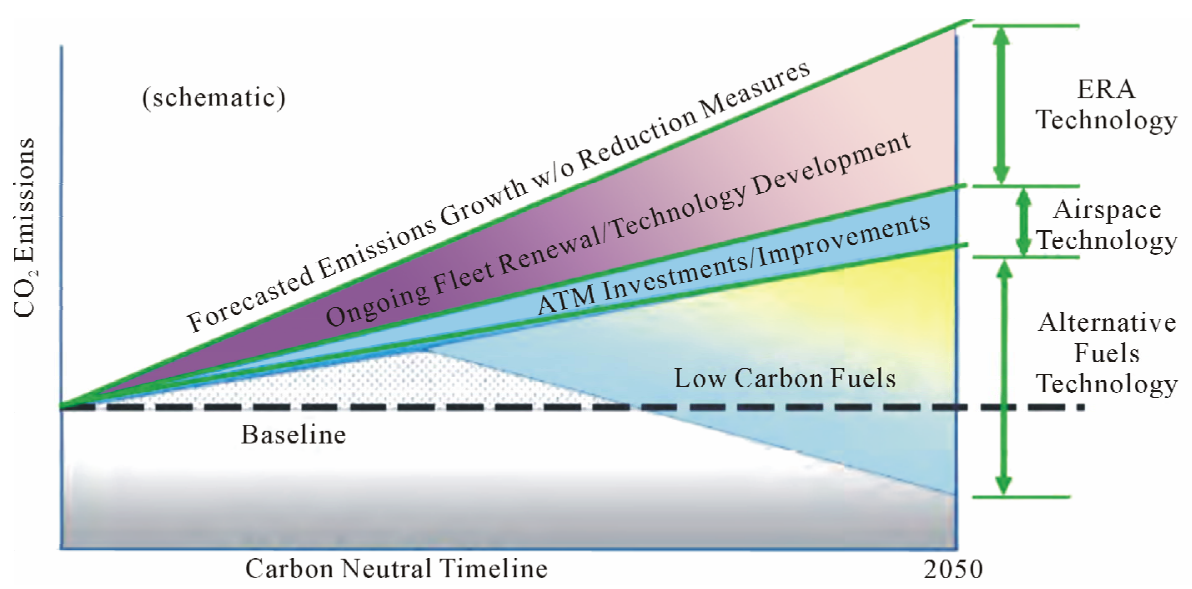

Figure 7. Key drivers for emissions reductions in aviation [28].

prices of such technology still remain the main issue for purchasing green products. GARDN is a business-led network of centres of excellence that brings together industry, university and government partners with the objective to reduce the environmental footprint of the aerospace industry. GARDN's mandate is to promote and to bring financial support to the environmental research in Canada in the area of green aviation. The seven themes of research targeted by GARDN are: Noise and source emissions reduction, materials and manufacturing processes, airport and aircraft operations, alternative fuels and product lifecycle management. Created in 2009, GARDN is a network of centres of excellence that brings together industry, university and government partners to lower noise and emissions pollution produced by the aerospace industry, and ultimately to reduce its ecological footprint. In creating GARDN, the Government of Canada has recognized the importance of being at the forefront of green aviation R\&D with world leaders who are defining the future of the aerospace industry [11].

Spread across NASA's existing portfolio of aeronautical research, green aviation is not considered part of a single project or programme. Green aviation represents an aim that has guided many of NASA's research goals since the earliest days of aviation, and especially after the environmental awareness and the energy shortages of the 1970s required inventing innovative ways to quiet airplanes, reduce air pollution and burn fuel more efficiently. In addition to aircraft-related improvements, green aviation touches on air traffic management, which focuses mostly on enabling aircraft to move more efficiently through the national airspace system, thus reducing noise, emissions and fuel burn. A greener future for aviation holds the promise of new life for airports, because people will be able to enjoy the convenience and commercial benefits of living near an airport without enduring the racket and fumes that are so aggravating today (Figure 8).

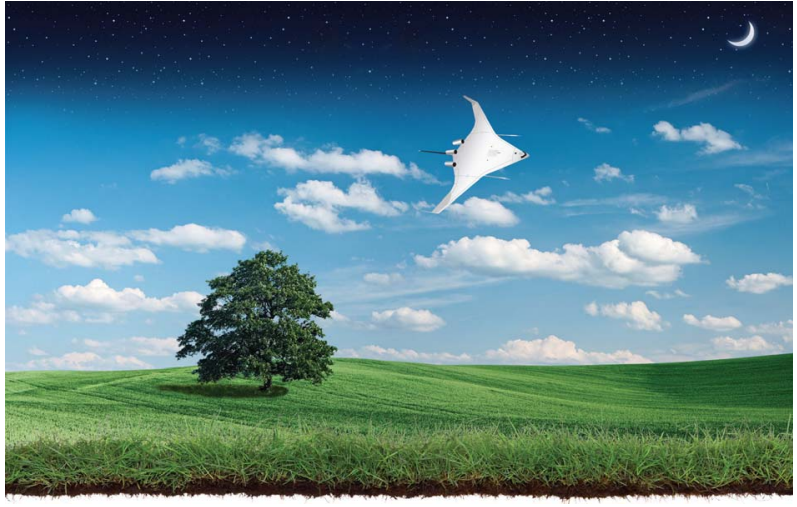

Figure 8. NASA's goal is to reduce aircraft fuel consumption, Emissions and noise simultaneously. Image credit: NASA.

NASA has a set of research goals that can be described as "green" because they relate to mitigating environmental impacts of aviation. NASA's goal is to reduce aircraft fuel consumption, emissions and noise simultaneously, which is a much more difficult challenge than working to reduce them individually. The challenge in this case is that the fuel consumed by the US comercial air carriers and the military releases more than 250 million tons of carbon dioxide $\left(\mathrm{CO}_{2}\right)$ into the atmosphere each year. $\mathrm{CO}_{2}$ is a greenhouse gas and a contributor to global warming. Other major emissions are nitric oxide (NO) and nitrogen oxide $\left(\mathrm{NO}_{2}\right)$, which together are called $\mathrm{NO}_{2}$ and contribute to ozone creation; sulfur oxides $\left(\mathrm{SO}_{2}\right)$; and particulates (often referred to as soot). Forty of the top 50 US airports are in areas that do not meet Environmental Protection Agency local air quality standards for particulate matter and ozone. Reducing $\mathrm{NO}_{2}$ emissions also reduces $\mathrm{SO}_{2}$ emissions. Reducing the amount of fuel burned reduces $\mathrm{CO}_{2}$ emissions.

NASA's emissions reduction goals are based on a standard known as International Civil Aviation Organization's Committee on Aviation Environmental Protec- 
tion Sixth Meeting, or CAEP/6. Most aircraft engines in use today meet or exceed CAEP/6. Related to this standard, NASA's goals are to create technology capable of enabling engines that emit 60 percent less $\mathrm{NO}_{2}$, by 2015 , 75 percent less by 2020 , and greater than 75 percent less by 2025 . The goal dates represent a technology readiness level of 6 , which is considered ready for flight testing. This is the point at which NASA traditionally transfers a new technology to industry for further development toward operational readiness and certification by governing authorities such as the Federal Aviation Administration [30].

Aircraft noise continues to be regarded as the most significant hindrance to increasing the capacity of the National Airspace System, largely because of nuisance noise near major metropolitan airports. Although the Federal Aviation Administration has invested more than $\$ 5$ billion in airport noise reduction programs since 1980 , the problem persists. The goal for future mission in this regard should be to develop aircraft technology and airspace system operations to shrink the nuisance noise footprint around each airport until it is about one-third of its current size by 2015 , about one-sixth its size by 2020 , and contained within the airport property boundaries by 2025.

NASA is working on ideas to deal with the environmental issues of fuel burn, emissions and noise. Some ideas have to do with improvements in technology; others have to do with using new technology in new ways such as follows:

- Changes in the way an airliner's transit through the nation's air traffic control system is managed, by allowing pilots to take off and climb directly to their cruising altitude or descend directly to touchdown, without leveling off periodically to check in with air traffic control along the way;

- Changes in aircraft design, such as the use of lightweight composite structures and means to increase laminar, or smooth, air flow over aircraft surfaces, can increase overall lift and reduce drag;

- Changes in engine design or operation might include ultra-high bypass turbofans, open rotor engines, use of alternative fuels or locating engines on the body of the aircraft in such a way that deflects engine noise upward to keep it from reaching the ground.

These improvements require less engine power for an aircraft to fly at the same speed and altitude, and thus represent important contributions to achieving the goal of reducing fuel burn rates by as much as 50 percent over current rates. An example of a "green" design change can be seen in the blended wing and body of the subscale, flying X-48B aircraft prototype. Other concepts may include capitalizing on the potential of advanced electrical power technologies such as batteries or fuel cells to reduce the amount of fuel needed.

NASA's green aviation research takes place at all four of the agency's aeronautical field centers, including the Ames Research Center at Moffett Field, Calif., Dryden Flight Research Center at Edwards Air Force Base, Calif., Glenn Research Center in Cleveland, and Langley Research Center in Hampton, Va. The programs are the Fundamental Aeronautics Program, Airspace Systems Program, Aviation Safety Program, Aeronautics Test Program, and the recently added Integrated Systems Research Program. Research into green aviation technology begins at an elementary level in the laboratory. For example, a new air traffic management or aircraft vehicle concept is first identified and matured within the Airspace Systems Program or Fundamental Aeronautics Program. The overarching goal of the Fundamental Aeronautics Program is to achieve technological capabilities necessary to overcome national challenges in air transportation including reduced noise, emissions and fuel consumption, and increased mobility through a faster means of transportation. This higher level research is clustered in the Environmentally Responsible Aviation Project, which is part of the Integrated Systems Research Programme.

Green Aviation \& Logistics Group [31] is a special interest group under Dubai Economic Development office, being developed solely to promote the importance of green Aviation \& logistics in the Middle-East. The Group has eventually developed as a collaborative network of green aviation \& supply chain experts, with a general or specific expertise in the areas, where aviation \& logistics companies can improve their environmental performance of the supply chain. The Green Aviation \& Logistics Group plans to have a training centre in the near future; where in there will be in-depth transfer of research results. The GALG member companies, authorities, governments and international companies and organizations, will have regular exchanges that will cover technical innovations and other drivers, like eco-design of engines, systems, GTL technology, fuel from algae, waste management, etc.

\section{Development of Sustainable Air Transportation System}

The titles "Sustainable Aviation" or "Green Aviation" are recently being used with increasing frequency to address the technological and socioeconomic issues facing the aviation industry to meet the environmental challenges of twenty-first century. Air travel continues to experience the fastest growth among all modes of transportation, especially due to many fold increase in demand in major developing nations and emerging economies of Asia, Latin America and Africa. Therefore, the 
environmental issues such as noise, emissions and fuel consumption, for both airplane and airport operations, have become important for energy and environmental sustainability [32].

While the aviation sector must continue to meet rising demand for air transport services, the industry understands it needs to diversify and conserve its fuel supplies into the future and work towards reducing its environmental impacts, particularly greenhouse gas emissions. In response to this challenge the global aviation industry has been one of the first industry groups to set ambitious greenhouse gas emission targets, aiming to achieve carbon neutral growth from 2020 and an aspirational goal of 50 percent reduction from 2005 levels by 2050. The utilization of advanced aircraft, fuel conservation and improved airspace management offer the most immediate ways to mitigate aviation's environmental impact. It is forecasted that by $2025,27,200$ new airplanes worth $\$ 2.7$ trillion would be needed. As a result of threefold increase in air travel by 2025 , it is estimated that the total $\mathrm{CO}_{2}$ emission due to commercial aviation may reach between 1.2 billion tonnes to 1.5 billion tonnes annually by 2025 from its current level of 670 million tonnes. The amount of nitrogen oxides around airports, generated by aircraft engines, may rise from 2.5 million tonnes in 2000 to 6.1 million tonnes by 2025 . The number of people who may be seriously affected by aircraft noise may rise from 24 million in 2000 to 30.5 million by 2025 . Therefore there is urgency to address the problems of emissions and noise abatement through technological innovations in design and operations of the commercial aircraft. The aviation sector needs a substitute for petroleum-based fuel to improve its ability to reduce emissions and also address energy security. This step is more difficult for the aviation sector because, relative to ground transportation, aviation fuel is constrained by a stricter set of safety, technological and regulatory requirements.

Among all modes of transportation, travel by airplanes and automobiles continues to experience the fastest growth. Currently, there are approximately 500,000 air vehicles (335,000 Active General Aviation Aircraft, 18,000 Passenger Aircraft, 90,000 Military Aircraft, 27,000 Civil Helicopters, and 30,000 Military Helicopters), and 750 million ground vehicles in service world-wide. They are responsible for $50 \%$ of petroleum (oil) consumption and $60 \%$ of all greenhouse gas (GHG) emissions worldwide. These numbers are forecasted to double by 2050 . Therefore the environmental issues such as noise, emissions and fuel burn (consumption), for both airplane and ground vehicles, have become important for energy and environmental sustainability. For example, a recent Swedish project explored three scenarios of air travel on a sustainable path in 2050 . The results suggest that slower aircraft configuration cruising at lower altitudes would entail a $56 \%$ cut of $\mathrm{CO}_{2}$ emissions compared to 2000 . If this technology is coupled with a shift to a weakened emphasis on economic growth and less hectic lifestyles, air travel would significantly increase in a sustainable and environmentally friendly way.

In its efforts to curb the global greenhouse gas emissions, the EU has adopted the IPCC's sustainable target level for $\mathrm{CO}_{2}$ concentrations in the atmosphere equivalent to $450 \mathrm{ppm} \mathrm{CO}_{2}$ level. This level implies the reducetion of global emissions of $\mathrm{CO}_{2}$ by $42 \%$ by 2050 compared to 2000 and by about $50 \%$ between 2050 and 2100 . A recent Swedish project explored three possible scenarios that may lead to sustainable air transport in $2050 \mathrm{im}-$ plying a stabilization of $\mathrm{CO}_{2}$ concentration in the atmosphere at $450 \mathrm{ppm}$. The study concluded that even though a $40 \%$ reduction of fuel intensity may be achieved by refinement of the conventional aircraft, this path is probably not sufficient to reach the target levels. On the other hand, lowering the speed and the altitude of cruising by using high speed propellers entail a $56 \%$ cut of $\mathrm{CO}_{2}$ emissions compared to year 2000 [33].

Based on these demands for air travel, Boeing has determined the outlook for airplane demand by 2025 as shown in Figure 9. As a result of three fold increase in air travel by 2025 , it is estimated that the total $\mathrm{CO}_{2}$ emissions due to commercial aviation may reach between 1.2 billion tonnes to 1.5 billion tones annually by 2025 from its current level of 670 million tonnes. The amount of nitrogen oxides around airports, generated by aircraft engines, may rise from 2.5 million tonnes in 2000 to 6.1 million tonnes by 2025 . The number of people who may be seriously affected by aircraft noise may rise from 24 million in 2000 to 30.5 million by 2025 [13]. Therefore there is urgency to address the problems of emissions and noise abatement through technological innovations in design and operations of the commercial aircraft.

Avions de Transport Régional (ATR, Paris)'s involvement for a sustainable air transport development goes back in time, as an active member of the European Regions Airline Association (ERA) and its important

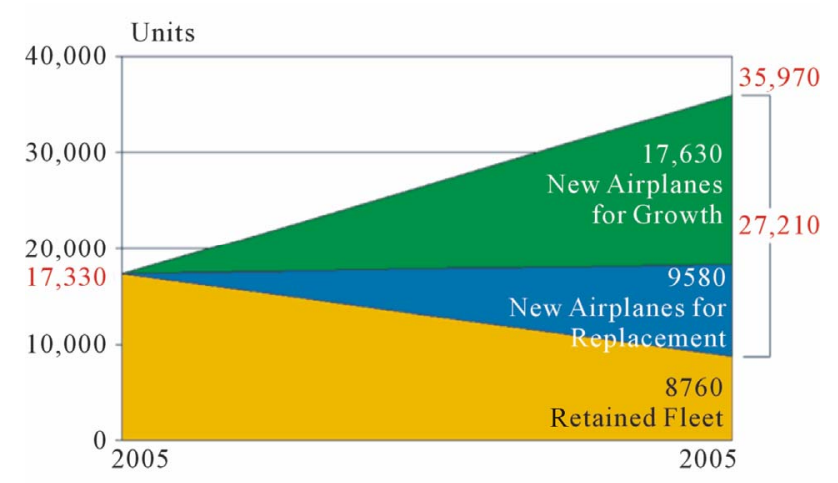

Figure 9. Boeing market forecast for new airplanes [13]. 
contribution to promote the economic and social contribution, as well as the good environmental record and future planned environmental progress, made by air transport in Europe's regions, in order to achieve public and political recognition At international level, ATR supports pro-actively the environmental vision of the Air Transport Action Group [34]: Promoting the concept of sustainable aviation to ensure an optimal balance between economic growth, social benefits and environmental responsibility. Promote the economic and social contribution, as well as the good environmental record and future planned environmental progress, made by air transport in Europe's regions, in order to achieve public and political recognition. ATR strongly supports the International Civil Aviation Organization (ICAO) in defining consistent rules and regulations to ensure a level playing field across the industry, to achieve noticeable environmental benefit.

The Air Transport Action Group [16] and Canada's Green Aviation Research and Development Network (GARDN) took the opportunity of the $6^{\text {th }}$ Aviation \& Environment Summit in Geneva to sign a cooperation agreement. GARDN - the Green Aviation Research and Development Network is a business-led Network of Centers of Excellence. Its mission is to promote aerospace technologies aimed at the protection of the environment. GARDN's activities are in support of the competitive excellence of Canadian aerospace products and services, the economic success of the member companies as well as the development and training of highly quailfied personnel. The two organizations intend to build on their respective mandates and networks to further foster and promote environmental research in aviation, particularly in the areas of sustainable aviation bio-fuels, sustainable development, industry collaboration and climate change. ATAG is a global industry-wide body that brings together all aviation industry and works to promote aviation's sustainable growth for the benefit of our global society. GARDN is a Business-Led Network of Centers of Excellence (BL-NCE) based in Montréal, Canada, whose mission is to promote aerospace technologies for the protection of the environment through collaborative research and development projects [16].

The aviation industry provides 56 trillion jobs worldwide and contributions of $\$ 2.2$ trillion in GDP. With the sustainable development of economies and the creation of jobs comes the responsibility to carefully manage the resources we are using and the impact that we have on the world. All parts of the commercial aviation industry are engaged in ways we can reduce environmental impact-from new technology and operational efficiencies to infrastructure development. A cooperation agreement with GARDN provides ATAG with a welcome opportunity to work collaboratively on reducing the environ- mental footprint on the planet, while maintaining benefits to the society and the economy.

The development of a local sustainable fuel supply for the aviation industry will create direct benefits for employment, and rural and regional development with a potential 12,000 new jobs by 2030 . It will also support the continued growth and ongoing contribution to the economy of the $\$ 39$ billion Australasian tourism industry. Taking a lead in the development of a sustainable aviation fuels industry could also create the opportunity for the region to export high value engineering know-how to the world. The development of a local sustainable fuel supply for the aviation industry will for instance create direct benefits for employment, and rural and regional development with a potential 12,000 new jobs by 2030 . Taking a lead in the development of a sustainable aviation fuels industry could also create the opportunity for the region to export high value engineering know-how to the world.

\section{Conclusions}

The paper discusses at length the broad conceptual parameters and operational aspects of "greening" and "sustainability" of the future aviation industry, which is rapidly growing. The main concerns related to the future growth of the industry are maintenance of air safety and ensuring emissions-free air quality, which is vulnerable for deterioration with the rapid pace of the growth in air-trafficking. The majority of aviation emissions are occurring at higher altitudes, thus generating greenhouse gases and potentially contributing to climate change and global warming. According to the findings of the paper, these emissions are primarily being controlled by the engine design, but total emissions can be reduced largely through improvements in fuel use efficiency. In this regard, a critical review of the available literature on the aspect shows that by using High-tech engines, propeller efficiency, advanced aerodynamics, low-drag airframe etc have resulted in higher level of fuel saving and. less gaseous emissions, matching international recommendations and reducing environmental impact besides reducing noise levels and increasing passenger comfort.

The global aviation industry is increasingly showing sensitivity toward environmental concerns and is choosing to invest in green technology products. Incidentally, the aviation industry is currently making great advances in technology such as: Revolutionary new plane designs; new composite lightweight materials; radical new engine advances; and the development of bio-fuels. Improvement in performance can be achieved by moving from a component-based design to a fully integrated design by including wing, tail, belly fairing, pylon, engine, high lift devices etc. into the solution. In this context, tightening 
regulations on the aviation industry to curb its emissions will drive green aviation technology market. Implementing green technologies, developing new initiatives in the bio-fuel field, using modern and fuel efficient fleet will certainly have a big impact on limiting the greenhouse gas emissions. Airlines must therefore reduce their consumption of oil-based jet fuel by investing in more fuelefficient technologies, nurturing the growth of alternative energies, and, more immediately, optimizing their business models.

Key drivers towards achieving carbon-neutral growth are identified to be: Fleet renewal, improving operational efficiency through full implementation of more efficient ATM and airport infrastructure, modernization of Engine retrofits \& airframe technology, use of bio-fuels etc. to name few. Imposition of Carbon tax, practicing Clean Development Mechanism, participating in Clean Sky Joint Technology Initiative can be helpful to try to attain carbon neutrality. Green Aviation manufacturing should therefore involve transformation of industrial operations in three ways: 1) Using Green energy; 2) Developing and selling Green products; and 3) Employing Green processes in business operations. Successful implementation of Green manufacturing will require adoption of an integrated three-step framework: a) Planning for Green as a core part of business strategy; b) Executing Green initiatives across the value chain by shifting towards Green energy, Green products and Green processes; and c) Communicating and promoting Green initiatives and their benefits to all stakeholders.

In conclusion, Green Aviation is a continuous process and the milestones can be achieved only by collective efforts from various spheres such as better aerodynamics in aircraft design and manufacturing; alternative and greener fuel sources such as fuel cells and bio-fuels; efficient engines; route optimization and network development; efficient air traffic management; coercive legislative policies; and positive economic measures.

\section{REFERENCES}

[1] Green Transport, "Resource Optimization in the Road Sector in PRC Main Report-Asian Development Bank and Ministry of Transport, People's Republic of China Collaborative Project," Asian Development Bank, 2009.

[2] EPA, "Draft Inventory of US Greenhouse Gas Emissions and Sinks: 1990-2010," 2012.

[3] IPCC, "IPCC Special Report Aviation and the Global Atmosphere," 1999.

[4] IPCC Working Group III, "The Fourth Assessment Report: Climate Change 2007-Mitigation of Climate Change, Chapter 5: Transport and Its Infrastructure," Data source is from World Bank, 2004.

[5] U. Eichhorst, "Adapting Urban Transport to Climate Change," In: GTZ, Ed., Sustainable Transport: A Sourcebook for
Policy Makers in Developing Cities, Wuppertal Institute, Eschborn, 2009.

http://www.sutp.org/index.php?option=com_docman\&tas $\mathrm{k}=$ cat_view\&gid=29\&Itemid=54\&lang $=$ en

[6] L. Tarrason, et al., "Study on Air Quality Impacts of NonLTO Emissions from Aviation," Norwegian Meteorological Institute, 2004.

[7] S. R. H. Barrett, et al., "Global Mortality Attributable to Aircraft Cruise Emissions", Environmental Science \& Technology, Vol. 44, No. 19, 2010, pp. 7736-7742. doi:10.1021/es101325r

[8] GAO, "Report to Congressional Committees: Aviation and Climate Change," United States Government Accountability Office, 2009.

[9] Environmental Protection Agency, "Inventory of US Greenhouse Gas Emissions and Sinks," 1990-2001. http://yosemite.epa.gov/oar/globalwarming.nsf/UniqueKe yLookup/LHOD5MJQ6G/\$File/2003-final-inventory.pdf

[10] ICAO, Environmental Report 2010, Chapter 2.

[11] National Aeronautics and Space Administration, "Environmentally Responsible Aviation (ERA) Project Partnership for Air Transportation Noise and Emissions Reduction (PARTNER)," NASA, 2008.

[12] Airbus, "Global Market Forecast 2000-2019 Toulouse," Airbus Ind., France, 2007.

[13] Boeing, "Current Market Outlook," Boeing Co., Seattle, 2008.

[14] IPCC, "Report on Aviation and the Global Atmosphere," A Special Report of IPCC Working Groups I and III in Collaboration with the Scientific Assessment Panel to the Montreal Protocol on Substances that Deplete the Ozone Layer, Intergovernmental Panel on Climate Change (IPCC).

[15] Carbon footprint. http://www.2celsius.org/new/2011/01/03/aviation-industr ys-attempt-at-flying-green

[16] ATAG, "ATAG and GARDN Sign Agreement to Promote Environmental Research in Aviation," 2012. http://www.newswire.ca/en/story/943107/atag-and-gardnsign-agreement-to-promote-environmental-research-in-av iation

[17] Imperial College London, "Green Aviation 2011: A Symposium," Organized by the Green Aviation Forum of Imperial College London, 2011.

https://workspace.imperial.ac.uk/greenaviation/Public/Gr een $\% 20$ Aviation\%202011.pdf

[18] IATA, "Aviation and Climate Change Pathway to Carbon-Neutral Growth in 2020," 2009.

http://www.iata.org/SiteCollectionDocuments/AviationCl imateChange_PathwayTo2020_email.pdf

[19] GAO, "Aviation and the Environment: NextGen and Research and Development Are Keys to Reducing Emissions and Their Impact on Health and Climate," US Government Accountability Office, 2008.

[20] Design Science and Technology Sub-Group, "Greener by Design, Mitigating the Environmental Impact of Aviation: Opportunities and Priorities," Report of the Greener by Design Science and Technology Sub-Group, 2005.

[21] D. McCollum, G. Gould and D. Greene, "Greenhouse 
Gas Emissions from Aviation and Marine Transportation: Mitigation Potential and Policies," Prepared for the Pew Center on Global Climate Change, 2009.

[22] A. Jane, J. A. Leggett, Elias, Bart and D. T. Shedd, “Aviation and the European Union's Emission Trading Scheme," CRS Report for Congress, Congressional Research Service, 2012. www.crs.gov

[23] N. Moharamnejad and S. Azarkamand, "Implementation of Green Productivity Management in Airline Industry," International Journal of Environmental Science and Technology, Vol. 4, No. 1, 2007, pp. 151-158.

[24] B. Saynor, A. Bauen and M. Leach, "The Potential for Renewable Energy Sources in Aviation," Imperial College, London, 2003. www.iccept.ic.ac.uk

[25] G. Rotorcraft, "Clean Sky Joint Technology Initiative," 7th Framework Programme, Green Rotorcraft ITD CA version 1, 2009.

[26] K. Lumpur, "Carbon-Neutral Growth by 2020," 2009. http://www.iata.org/pressroom/pr/Pages/2009-06-08-03.a spx

[27] ICCT, "Efficiency Trends for New Commercial Jet Aircraft: 1960-2008," 2009.
[28] NRC, "NRC Meeting of Experts on NASA's Plans for System-Level Research in Environmental Mitigation," The Gaylord National Resort \& Convention Center, National Harbor, MD, 2009.

http:/www.aeronautics.nasa.gov/calendar/20090514.htm

[29] GBI Research Group, "Green Aviation Market to 2020 Stringent Regulations to Drive Investment in Green Technologies," 2010.

[30] S. Baughcun, et al., "Scheduled Aircraft Emission Inventories for 1992," Database Development and Analysis, NASA Contract Report No. 4700, NASA Langley Research Centre, 1996.

[31] Green Aviation \& Logistics Group. http://www.cssgroupsite.com/lighthouse/green-aviation-1 ogtics-group-realises-its-vision-towards-protecting-the-en vironment

[32] Sustainable (Green) Aviation, 2012. http://web2.aiaa.org/CourseDetail.aspx?id=4601

[33] J. Akermann, "Sustainable Air Transport—on Track in $2050, " 2005$.

[34] Air Transport Action Group (ATAG, 2010), "Beginner's Guide to Aviation Efficiency," 2010. www.enviro.aero 